\title{
Strategies for academic leadership towards increasing productivity in higher education institutions; business education case
}

\author{
Magdalena IORDACHE-PLATIS \\ University of Bucharest, Bucharest, Romania \\ magdalena.iordache-platis@drept.unibuc.ro
}

\begin{abstract}
Higher education institutions face a lot of challenges in the contemporary context. Labour market is s strict evaluator of the graduates' competences and skills and thus, of the study programmes. An attractive university is a university with a large demand for studies, with many partners and projects, with a high visibility at national and international level, with a considerable research production. At present, the lack of resources characterizes the difficult situation for decision making process which is a real challenge for the academic leadership. On one hand, the competiton requires the need of continuous development and of differentiation strategy while on the other hand, insufficient financial, human, material, informational resources, including time as a specific restriction generate huge opportunities and threats for institutions. Possibilities of being efficient are to be explored. The aim of this paper is to explore possible strategies to increase productivity in higher education institutions. Main objectives of the study are the following: a). to define productivity in higher education institutions, on the basis of the academics' perceptions, as well as of students' perceptions; b). to provide a diagnosis of the current state of the prductivity in higher education institutions; c). to contribute to new clarifications on leadership strategies for increasing productivity in higher education institutions. Based on the literature review, the paper reveal proper answers to questions, such as: what is productivity, how is it measured, what is its impact, which are the increasing possibilities in business context. The study methodology is also based on a questionnaire dedicated to the two groups of respondents - academics and students.Their perceptions are then compared in order to reveal the common view. Main output of the research include: a). A new conceptual clarification for the productivity in higher education institutions; b). A proposal of leadership strategies from business to academic environment.
\end{abstract}

Keywords: leadership, productivity, higher education, strategies, quality assurance.

\section{Introduction: Contemporary context for higher education institutions}

Higher education institutions face many challenges in the contemporary context of socioeconomical characteristics of the macro-environment. From a static, traditional behavior, institutions have evolved towards a more or less dynamic, modern behavior. Since the former involves mainly activities generated from didactical or educational mission of the institution, the latter implies differentiation from the other institutional missions referring to research and society-higher education institution relationship.

Higher education institutions cannot be compared with ordinary business companies where competition is always considered; private businesses appear and disappear from the market and the same owners or entrepreneurs start other businesses, as well as new entrants become active in the same or different industries, while other entities diminish their market presence and even leave the sector. Higher education 
institutions do not easily appear or disappear. In general, they are institutions for long run. Nevertheless, changes take place in the higher education sector, some generated from national context, some from international trends.

Contemporary context of the higher education institutions reveals at least three characteristics in terms of factors that have an increasing importance for higher education institutions:

- internationalization - Paleari (2015) consider internationalization as one of the four key element of the university strategy, together with quality, excellence in research and identity; at the same time, he considers internationalization important for research and mobility, especially for students;

- national positioning - national context is important for the institutional effective evolution. Tveit (2015) show that from the societal mission, universities must be active and efficient in order to contribute to the growth in the region they belong to, while Beretz (2015) shows the still dependency of national systems and the control from national administrators;

- internal efficiency - Pruvot et al. (2015) states that efficiency must be considered when actions lead to economic gains, and therefore, he connects the efficiency issue with the funding process, even mergers of institutions and concentration processes, but always in a direct link with the institutional missions.

In other words, a correct understanding of the context for higher education sector reveals institutional changes that are generated from external environment, such as international and national and internal environment, such as institutional characteristics. How productivity is perceived by the academic community is important and reflected in proper actions, activities and internal processes. Next, productivity will be explained from a literature review perspective, as well as from two interested parties' way of thinking academics and students.

\section{Productivity and leadership strategies in higher education institutions Productivity and efficiency -in business and higher education sector}

Productivity is not a new concept. The Webster's Universal English Dictionary (2004) explains productivity as the state of being productive which for businesses means the ratio output - input, while in the Webster's Universal English Thesaurus dictionary (2004), the term productive have several meanings: copious, fertile, fruitful, luxuriant, plenteous, prolific, teeming, as well as causative, constructive, creative, efficient, life-giving and producing. In the Webster's Universal Business Dictionary (2004), productivity is also explained as a measure which compare the output with the input.

Productivity in the business industry is not a theoretical issue, but a practical one. At Aveta Business Institute providing courses online as Six Sigma explains from the very beginning the importance of the productivity in practical activity of a business, being considered its impact on business itself: efficiency increases, resources are better used, profits grow, costs diminish, market position is improved, new customers are attracted, prices become more competitive etc.

Therefore, productivity in business is connected to the characteristic of a person involved in a practical activity, of being productive and to the result of the activity, being a consequence of the resources' usage. 
In higher education sector, the meaning of the productivity is not clear. Estermann (2015) explains the pressure on many universities in different countries to prove their productivity and efficiency; he provides examples of decisions made in Ireland, Sweden, and Netherlands which meant cost diminishing, or study programmes rationalization, or budget differentiations.

In research area, productivity can be considered at macro and micro-levels when innovative processes are carried out and generated from concrete investments (Gheorghiou, 2015); he also reveals the importance of the investment in research infrastructure.

A general improvement of the efficiency in higher education institutions implies new management approach and new funding system, as well as new developments related to institutional profile and structural changes, as Wahlfors (2016) explains; the author's propositions refers to new funding formula for institutions, ministry involvement, clear targets for institutions, structural development and many other issues. According to the study, main results conduct to solutions for increasing efficiency in higher education institutions through more cooperation among universities, among universities and other entities, as research institutes, more joint use of research infrastructure and resources.

At the same time, a special event of IREG Observatory on Academic Ranking and Excellence will take place in March 2017 on excellence as the university driving force, and inviting specialists to discuss about the excellence - its role, its meaning as set of standards and the need of redefining excellence for universities. In other words, the continuing interest on excellence proves the need of having a clear understanding of what productivity means in order to be able to implement pertinent measures for institutional development in higher education sector.

\section{Academics' and students' perceptions on productivity in higher education institution}

A simple research was conducted at the University of Bucharest in order to understand the way of thinking of two stakeholder groups - academics and student. A questionnaire was designed with two parts:

I. Open and closed questions. The respondents were first asked to mention the most appropriate words expressing productivity and productive in higher education institutions, according to the suggestions already written and according to their own beliefs.

II. Then, the respondents were invited to express the value of truth related to some sentences based on a Lickert scale of five levels.

The number of valid questionnaire were 172 for students and 84 for academics. The characteristics of the respondents are described in Table 1. and Table 2.

Table 1. Characteristics of the respondents - students

\begin{tabular}{|l|l|l|l|}
\hline Level of study/ Structure & Female & Male & Total \\
\hline Undergraduate level & 84 & 40 & 124 \\
\hline Graduate level & 36 & 12 & 48 \\
\hline Total & 120 & 52 & 172 \\
\hline
\end{tabular}


Table 2. Characteristics of the respondents - academics

\begin{tabular}{|l|l|l|l|}
\hline Academic position & Female & Male & Total \\
\hline Assistants and lecturers & 40 & 12 & 52 \\
\hline $\begin{array}{l}\text { Associate professors and } \\
\text { professors }\end{array}$ & 11 & 21 & 32 \\
\hline Total & 51 & 33 & 84 \\
\hline
\end{tabular}

Source: Authors' own research.

Responses got in the first part of the study are included in Table 3 . The responses considered were only those that were accepted at least by $20 \%$ of respondents, meaning 34 students and 16 academics.

Table 3. Productivity and productive understanding - groups' perceptions

\begin{tabular}{|c|c|c|c|}
\hline Productivity/productive & $\begin{array}{l}\text { Students' } \\
\text { responses }\end{array}$ & $\begin{array}{l}\text { Academics' } \\
\text { responses }\end{array}$ & $\begin{array}{l}\text { Convergent } \\
\text { perceptions }\end{array}$ \\
\hline \multicolumn{4}{|l|}{ Productivity } \\
\hline - $\quad$ efficiency & $\checkmark$ & $\checkmark$ & $\checkmark$ \\
\hline - $\quad$ quality & & $\checkmark$ & \\
\hline - formula & $\checkmark$ & $\checkmark$ & $\checkmark$ \\
\hline - $\quad$ indicator & & $\checkmark$ & \\
\hline \multicolumn{4}{|l|}{ Other responses } \\
\hline $\begin{array}{l}\text { - } \begin{array}{l}\text { organizational } \\
\text { capacity }\end{array} \\
\text { a }\end{array}$ & & $\checkmark$ & \\
\hline - $\quad$ profit & $\checkmark$ & & \\
\hline - $\quad$ satisfaction & $\checkmark$ & & \\
\hline \multicolumn{4}{|l|}{ Productive } \\
\hline - $\quad$ fertile & & $\checkmark$ & \\
\hline - $\quad$ fruitful & $\checkmark$ & $\checkmark$ & $\checkmark$ \\
\hline - $\quad$ prolific & $\checkmark$ & & \\
\hline - $\quad$ constructive & $\checkmark$ & $\checkmark$ & $\checkmark$ \\
\hline - $\quad$ creative & $\checkmark$ & $\checkmark$ & $\checkmark$ \\
\hline - $\quad$ efficient & $\checkmark$ & $\checkmark$ & $\checkmark$ \\
\hline \multicolumn{4}{|l|}{ Other responses } \\
\hline - $\quad$ to produce & $\checkmark$ & & \\
\hline - to be active & $\checkmark$ & $\checkmark$ & $\checkmark$ \\
\hline$-\quad$ no loss & & $\checkmark$ & \\
\hline
\end{tabular}

Source: Authors' own research.

In the second part of the study, the results were synthetized in Table 4.

Table 4. Productivity and productive understanding - groups' perceptions

\begin{tabular}{|l|l|c|c|}
\hline $\begin{array}{l}\text { Crt. } \\
\text { No. }\end{array}$ & Question/Sentence & $\begin{array}{l}\text { Lickert score - } \\
\text { students' group }\end{array}$ & $\begin{array}{l}\text { Lickert score - } \\
\text { academics' group }\end{array}$ \\
\hline 1. & $\begin{array}{l}\text { In higher education institutions, productivity } \\
\text { cannot be measured }\end{array}$ & 2.86 & 3.15 \\
\hline 2. & $\begin{array}{l}\text { Productivity is related to students' } \\
\text { performance }\end{array}$ & 4.33 & 4.28 \\
\hline 3. & $\begin{array}{l}\text { An efficient university is a ranking based } \\
\text { visibility of the institution. }\end{array}$ & 2.65 & 4.82 \\
\hline 4. & $\begin{array}{l}\text { Productivity is not important in educational } \\
\text { sector. }\end{array}$ & 2.13 & 1.62 \\
\hline 5. & $\begin{array}{l}\text { Productivity is excellency in higher education } \\
\text { institutions. }\end{array}$ & 3.26 & 4.34 \\
\hline 6. & Highest students' satisfaction is what counts & 4.24 & 3.45 \\
\hline
\end{tabular}




\begin{tabular}{|l|l|c|c|}
\hline & to improve productivity. & 3.17 & 2.86 \\
\hline 7. & $\begin{array}{l}\text { Each user measures differently the } \\
\text { institutional productivity }\end{array}$ & 2.96 & 3.16 \\
\hline 8. & Productivity should be standardized. & 4.18 & 3.65 \\
\hline 9. & $\begin{array}{l}\text { Productivity is only a quantitative expression } \\
\text { of the current activity. }\end{array}$ & & \\
\hline
\end{tabular}

Source: Authors' own research.

Therefore, between the two respondents' groups some similarities and controversies have been identified. Both of them understand productivity in terms of efficiency, specific formula, creativity etc, but only the students see productivity as an indicator of their satisfaction, while the academics only consider productivity as connected to ranking based visibility. In Figure 1. these similarities and differences are simply shown.

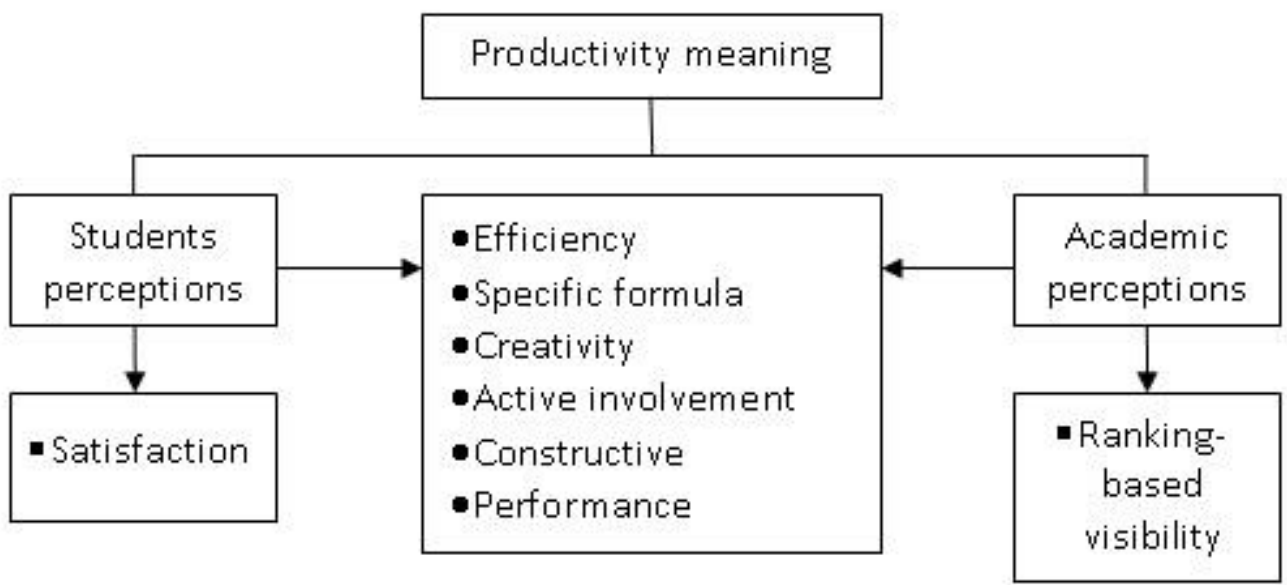

Figure 1. Productivity meaning

Source: Source: Authors' own research.

Productivity in higher education institutions can be defined as following:

- The institutional way of acting towards achieving student's satisfaction. This is the students' perception;

- The consequence of the entire activity reflected in the ranking position of the institution. This is the academics perception.

In higher education institutions, there are continuously made many efforts to increase their students' satisfaction. In different external evaluation processes, national or international are very much considered. Annually, students evaluate teaching as a general rule, and from institution to institution they may evaluate many more activities, such as: administrative performance, accommodation, carrier counselling services etc.

In terms of rankings, in many cases, they include in their methodologies criteria that are not much related to students' satisfaction. For instance, in Quacquarelli Symonds international ranking, a high score universities can get from research productivity, meaning publications in visible journals and citations and also from the academics' reputation and employers' reputation. 
From the two criteria combination, several institutional behaviors and strategies are revealed, as seen in Table 5 .

Table 5. Productivity based strategies and behaviors for higher education institutions

\begin{tabular}{|l|l|l|l|}
\hline \multicolumn{2}{|l|}{ Critria } & \multicolumn{2}{l|}{ Students' satisfaction } \\
\cline { 3 - 4 } \multicolumn{2}{l|}{} & Poor & High \\
\hline \multirow{2}{*}{$\begin{array}{l}\text { Ranking } \\
\text { position }\end{array}$} & Visible & False productivity strategy & Proper productivity strategy \\
\cline { 2 - 4 } & Less visible & $\begin{array}{l}\text { In developing productivity } \\
\text { strategy }\end{array}$ & $\begin{array}{l}\text { Prioritized productivity } \\
\text { strategy }\end{array}$ \\
\hline
\end{tabular}

Source: Authors' own research.

- False productivity strategy - it refers to the case of a visible institution in a ranking, but with poor interest towards students and theirl level of satisfaction. This is a false strategy, since it cannot last for a long time. In fact, positions in rankings modify at least once a year;

- Proper productivity strategy - this corresponds to a correct combination of the two perspectives - academics and students. The client are satisfied, the results are good or very good reflected in different indicators, nd the rankings see this;

- In developing productivity strategy - institution is less positioned in different rankings, but, internally, students are satisfied. This is the best example of case of internal based changes and difficult external competition to face;

- Prioritized productivity strategy - this is the case of both low interests - internal and external one. This type of institution will not be able to survive, unless a strong external support. Even so, it will offer unattractive study programme, and the number of students will decrease year by year.

Higher education institutions have to understand their way of acting and be honest with themselves about what type of strategy characterizes them. After that, they will be able to move forward, from an unattractive strategy to a more productive oriented one.

At this stage a new question arises: what should higher education do in order to connect the two perceptions on productivity - the ranking approach, which is the management way of acting with the client approach, which is the student satisfaction consideration. Strategies are defined by top management, but their implementation is done through employees' involvement. Therefore, productivity strategy change must be understood by the academic community and be integrated in daily way of acting. This is why, it is so connected with the idea of quality culture.

\section{Leadership strategies towards increasing productivity in higher education institutions}

The study reflects a need for a new understanding of the productivity in higher education institutions, from a quantitative approach, to a qualitative one. In Figure 1. These changes are clearly stated. 


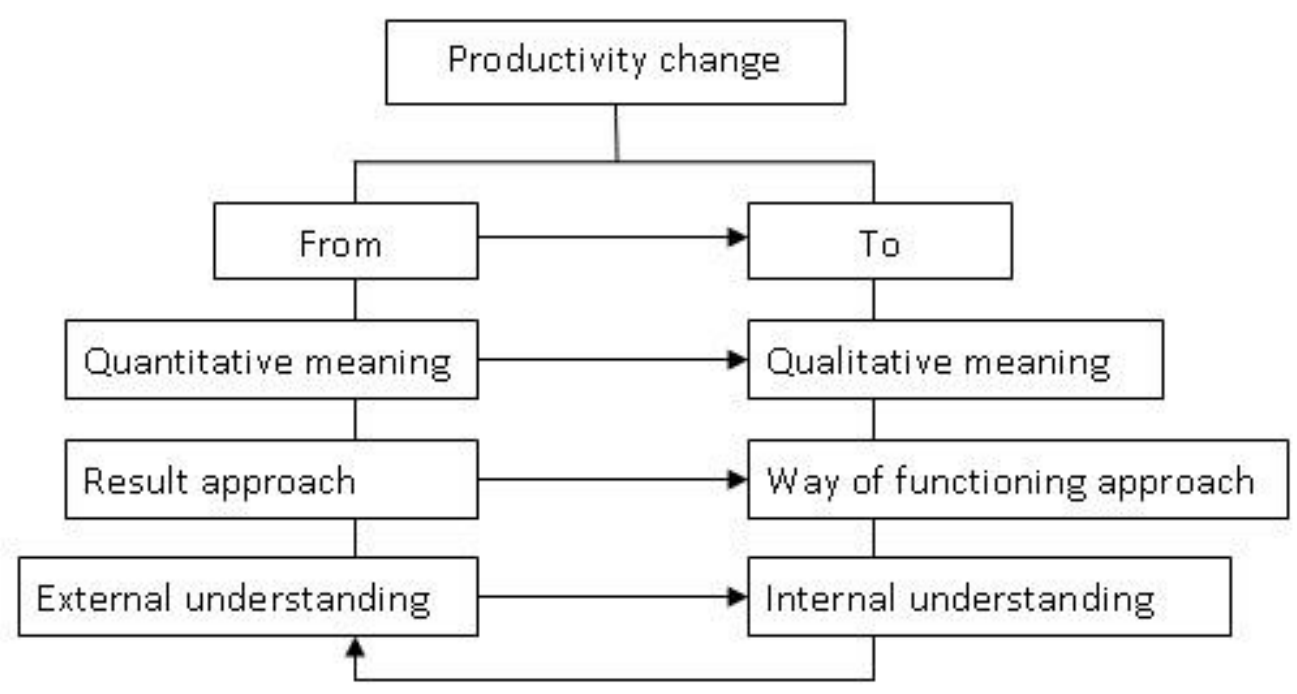

Page | 261

Figure 2. Productivity change

Source: Source: Authors' own research.

At this stage a new question arises: what should higher education do in order to connect the two perceptions on productivity - the ranking approach, which is the management way of acting with the client approach, which is the student satisfaction consideration.

Bak-Maier (2012) explains thirteen productivity strategies which could be implemented in current businesses. Some of them could be adapted and implemented in higher education institutions. The most relevant strategies to increase productivity in higher education institutions could be converted into principles, as seen in Figure 3.

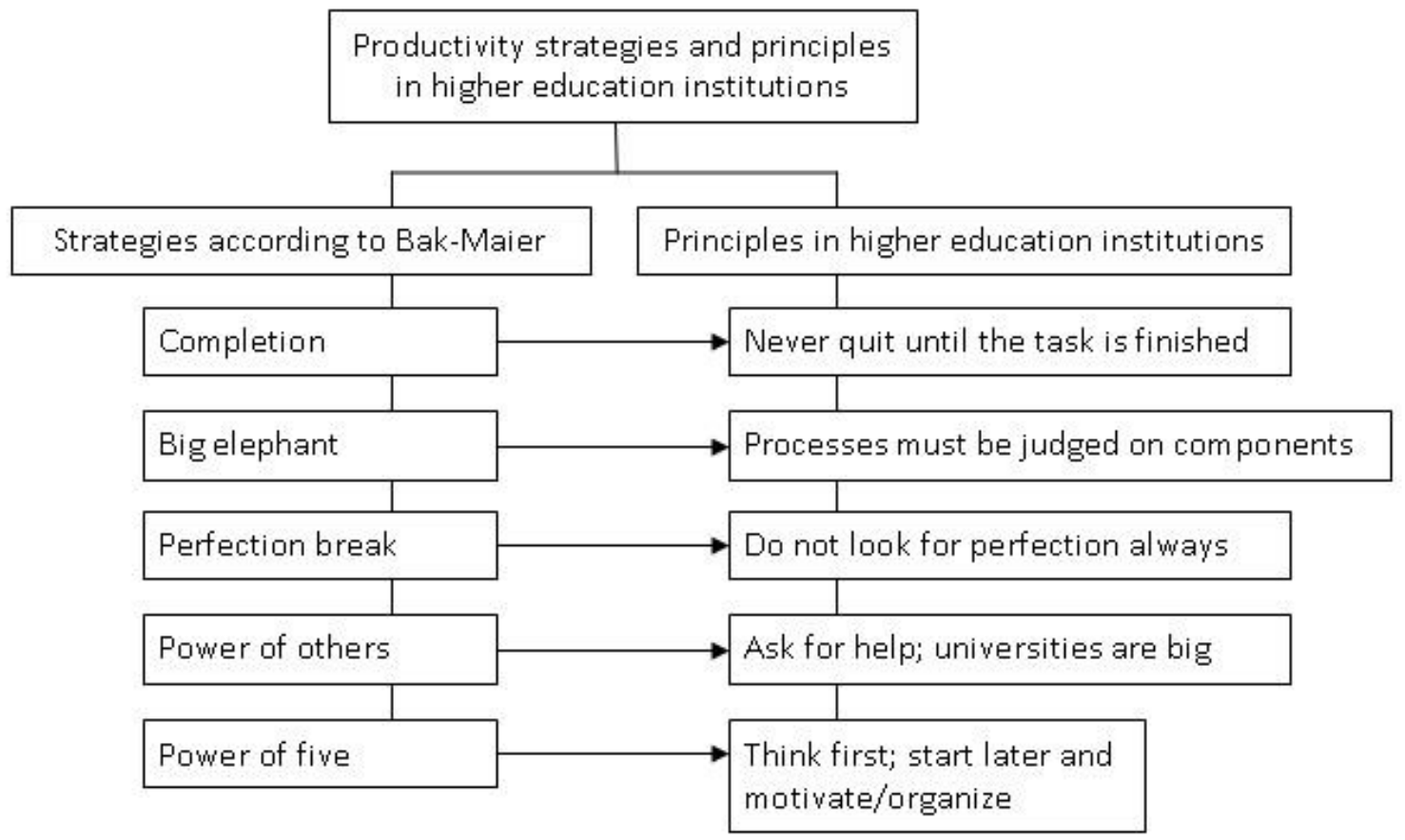

Figure 3. Productivity strategy

Source: Source: Authors' own research. 
Many similar strategies can be identified with only a little bit of human resource management knowledge. Thus, strategies can contain both deliberate components as well as emergent ones (Bolisani and Bratianu, 2017) in order to achieve their vision and mission. Future is not just an extrapolation of the present time and it cannot be conceived by using a deterministic mind; we need to develop a probabilistic thinking (Bratianu, 2007) which means to anticipate probable events to happen and to evaluate to the best of your knowledge their probabilities. Also, future is not a linear evolving of the present time, which means to use in shaping it a nonlinear pattern of thinking (Bratianu, 2009) where outcomes are not proportional to inputs in the process anymore. While many people relate the productivity of the intellectual work directly to the efforts made by using a linear metric, academic productivity has a different meaning since professors' work cannot be measured with the same metric used for industrial workers. Intellectual work is strongly nonlinear and new correlations should be constructed in order to evaluate how much and how efficient professors and researchers perform their academic tasks. Also, it should be taken into consideration the type of university governance which can stimulate or not the productivity of professors and researchers (Bratianu et al., 2017).

\section{Conclusion}

Productivity in higher education institutions is an interesting topic for leadership and management strategies. From a theoretical point of view, productivity involves technical understanding, being a consequence or a result of the relationship between input and output. More than this, the practical approach involves a transition from what is external seen as being productive, to internal understanding of performance. In other words, for higher education institutions, the trend is from the current external approach of productivity seen through ranking position, to internal changes generated from students' satisfaction increasing need.

Future researches might take into considerations some of the following issues: (a) Quality indicators and their need of improvement based on productivity new understanding; (b) Employers' perception on higher education institutions' productivity; and (c) Measurements of the productivity from qualitative point of view.

\section{References}

Aveta Business Institute, http://www.sixsigmaonline.org/six-sigma-training-certificationinformation/the-importance-of-productivity-in-business/ (accessed March 5, 2017).

Estermann, T. (2015). EUA Public Funding Observatory, http://www.eua.be/Libraries/default-document-library/2.pdf, p. 8 (accessed March $5,2017)$.

Bak-Maier, M., (2012). Get productive! Boosting your productivity and getting things done, Capstone, pp. 157-157.

Beretz, A., (2015) in University Leaders' Perspectives. Governance and Funding, http://www.eua.be/Libraries/publications-homepage-list/university-leaders'- 
perspectives-governance-and-funding.pdf?sfvrsn=2, pp 6-20)accessed 5 March, 2017).

Bolisani, E. and Bratianu, C. (2017). Knowledge strategy planning: an integrated approach to manage uncertainty, turbulence, and dynamics. Journal of Knowledge Management, 21(2), pp. 233-253.

Bratianu, C. (2007). Thinking patterns and knowledge dynamics. In D. Remeny (Ed.). Proceedings of the $8^{\text {th }}$ European Conference on Knowledge Management (pp. 152156), Consorci Escola Industrial, Barcelona, Spain, 6-7 September 2007. Reading: Academic Conferences Limited.

Bratianu, C. (2009). The frontier of linearity in the intellectual capital metaphor. In C. Stam (Ed.). Proceedings of the European Conference on Intellectual Capital (pp.97-103), Inholland University of Applied Sciences, Haarlem, The Netherlands, 28-29 April 2009.

Bratianu, C., Iordache-Platis, M. and Prelipcean, G. (2016). The role of legislation and organizational culture in shaping academic leadership. In F. Pinzaru and C. Bratianu (Eds.). Proceedings of the $12^{\text {th }}$ European Conference on Management, Leadership, and Governance (pp. 17-23), Faculty of Management, SNSPA, Bucharest, Romania, 10-11 November 2016. Reading: Academic Conferences and Publishing International.

Gheorghiou, L., (2015). Value of research, http://www.eua.be/Libraries/nrcactivities/georghiou-2015_the-value-of-research.pdf, p. 6 (accessed March 5, 2017).

Paleari, S., (2015) in University Leaders' Perspectives. Governance and Funding, http://www.eua.be/Libraries/publications-homepage-list/university-leaders'perspectives-governance-and-funding.pdf?sfvrsn=2, p.p 6-20, (accessed 5 March, 2017).

Pruvot et al., (2015), Designing strategies for fficient funding of universities in Europe, http://www.eua.be/Libraries/publications-homepage-list/designing-strategies-forefficient-funding-of-universities-in-europe.pdf?sfvrsn=4, pp. 1-68, (accessed 4 March, 2017).

Tveit, M., S., (2015) in University Leaders' Perspectives. Governance and Funding, http://www.eua.be/Libraries/publications-homepage-list/university-leaders'perspectives-governance-and-funding.pdf?sfvrsn=2, pp. 6-20, )accessed 5 March, 2017).

Wahlfors, L., (2016). Efficency through 1. Performance-based management \& funding, 2. Profiling and structural development, http://www.eua.be/Libraries/SGmeetings/sg-3-2016_item2_annex-2_efficiency-measures-in-fi_leena-wahlfors.pdf (accessed March 5, 2017).

Aveta Business Institute, http://www.sixsigmaonline.org/six-sigma-training-certificationinformation/the-importance-of-productivity-in-business/ (accessed March 5, 2017).

Webster's Universal Business Dictionary (2004), David Dale House, Scotland, p. 237.

Webster's Universal English Dictionary (2004), David Dale House, Scotland, p. 351.

Webster's Universal English Thesaurus dictionary (2004), David Dale House, Scotland, p. 217. 